\title{
EDUKASI DAN PENDAMPINGAN PENYUSUNAN LAPORAN KEUANGAN UMKM KULINER XYZ
}

\author{
Agung Dinarjito ${ }^{1)}$; Aldi Bilqisthy Pratama; Dessyka Sitanggang; Faizul Abrori; Fayiz Alfitra RM; Lamhot \\ Doli Tambunan; Muhammad Arfan; Muhammad Rajul Muzik; Muhammad Taufiq Hidayat; Nanda \\ Sulfiandra; Putra Jaya Bukit
}

1) agung.dinarjito@pknstan.ac.id, Politeknik Keuangan Negara STAN

\begin{abstract}
This community service activity aims to provide education and assistance for Micro, Small and Medium Enterprises (MSMEs) by providing an understanding of the importance of preparing financial reports and providing assistance in preparing financial reports using the SI APIK application. The method of implementing the activity is carried out in several stages, namely the first stage is planning and observation, the second stage is assistance in the preparation of financial reports using the Si APIK application, the third stage is the preparation of financial reports until August 2021, and the last stage is making video tutorials using the SI APIK application and making posters regarding the preparation of financial reports. MSME XYZ which is engaged in the culinary field is the object chosen and located in Central Java. The result of this activity is that MSME XYZ is able to make financial reports for the month of August using the Si APIK application
\end{abstract}

Keywords : Community service activity, financial report, MSME, Si APIK.

Abstrak

Kegiatan pengabdian masyarakat ini bertujuan untuk mmeberikan edukasi dan pendampingan bagi usaha Mikro, Kecil, dan Menengah (UMKM) dengan memberikan pemahaman tentang pentingnya penyusunan laporan keuangan dan memberikan pendampingan penyusunan laporan keuangan menggunakan aplikasi SI APIK. Metode pelaksanaan kegiatan dilakukan dengan beberapa tahap, yaitu tahap pertama adalah perencanaan dan observasi, tahap kedua adalah kegiatan pendampingan penyusunan laporan keuangan menggunakan aplikasi Si APIK, tahap ketiga penyusunan laporan keuangan sampai dengan bulan Agustus 2021, dan tahap terakhir adalah pembuatan video tutorial penggunaan aplikasi SI APIK dan pembuatan poster mengenai penyusunan laporan keuangan. UMKM XYZ yang bergerak dibidang kuliner merupakan obyek yang dipilih dan berlokasi di Jawa Tengah. Hasil kegiatan ini adalah bahwa UMKM XYZ mampu membuat laporan keuangan bulan Agustus dengan menggunakan aplikasi Si APIK.

Kata Kunci : Pengabdian kepada masyarakat, laporan keuangan, UMKM, SI APIK.

\section{PENDAHULUAN}

UMKM menjadi salah satu tulang punggung pertumbuhan ekonomi Indonesia. Hal ini ditunjukkan dari data Kementerian Koperasi dan Usaha Kecil dan Menengah pada bulan Maret 2021 yang menyatakan bahwa jumlah UMKM mencapai 64,2 juta dengan kontribusi terhadap Produk Domestik Bruto sebesar 61,07 persen. Keumdian, UMKM mampu menyerap 97 persen dari total tenaga kerja yang ada, serta dapat menghimpun sampai 60,42 persen dari total investasi di Indonesia (Kementerian Keuangan, 2021).

Staf khusus Menteri Koperasi dan UKM, M. Riza Damanik menyatakan bahwa pihaknya optimis ekspor UMKM akan menngkat menjadi 15,12\% pada tahun 2021 walaupun dalam masa pandemi covid-19 (Rasti, 2021). Dalam peta jalan (road map) pengembangan koperasi dan UMKM tahun 2021-2024, ditargetkan bahwa koperasi dan UMKM akan memberikan kontribusi PDB di tahun 2024 sebesar 62,36\% (Santia, 2021).

Berdasarkan Undang-Undang Nomor 20 Tahun 2008 tentang Usaha Mikro, Kecil, dan Menengah (UMKM) dijelaskan bahwa UMKM merupakan perusahaan kecil yang dimilik dan dikelola oleh seseorang atau dimiliki oleh sekelompok kecil orang dengan jumlah kekayaan dan pendapatan tertentu. Kementerian Koperasi dan UKM RI melaporkan bahwa secara jumlah unit, UMKM memiliki pangsa sekitar 99,99\% (62.9 juta unit) dari total keseluruhan pelaku usaha di Indonesia (2017), sementara usaha besar hanya sebanyak 0,01\% atau sekitar 5400 unit. Usaha Mikro menyerap sekitar 107,2 juta tenaga kerja (89,2\%), usaha kecil 5,7 juta (4,74\%), 
dan usaha menengah 3,73 juta $(3,11 \%)$; sementara usaha besar menyerap sekitar 3,58 juta jiwa (Haryanti \& Hidayah, 2019).

Namun, di dalam kondisi pandemi covid-19, sebanyak 1.785 koperasi dan 163.713 pelaku usaha mikro kecil menengah terdampak pandemi Covid-19 (Fadila, 2020). Untuk membangkitkan kembali UMKM tersebut, pemerintah telah memberikan berbagai bantuan, salah satunya melalui bantuan uang kepada UMKM. Kemudian, perbankan dan lembaga keuangan juga memberikan kemudahan bagi UMKM untuk mendapatkan pinjaman modal.

Modal menjadi faktor penting untuk mengembangkan usaha. Untuk mendapatkan pinjaman modal dari lembaga keuangan, laporan keuangan menjadi sangat penting karena melalui laporan keuangan tersebut, bank dan lembaga keuangan dapat menilai kemampuan membayar pinjaman dari UMKM tersebut. Selain itu, laporan keuangan sebenarnya sangat penting untuk dapat digunakan dalam mengevaluasi operasi usaha. Untuk melihat keuntungan usaha, maka catatan akuntansi dalam bentuk laporan keuangan perlu dibuat.

Seperti diketahui, banyak UMKM yang tidak melakukan penyusunan laporan keuangan dikarenakan tidak memahami cara membuat laporan keuangan atau malah membuat laporan keuangan dianggap pekerjaan yang rumit. Namun, dalam pekembangan saat ini telah banyak aplikasi penyusunan laporan keuangan UMKM yang tersedia di platform smartphone dan web. Salah satunya adalah SI APIK yang dibuat oleh Bank Indonesia bekerjasama dengan Ikatan Akuntansi Indonesia dan pihak yang berkepentingan dengan UMKM.

Aplikasi SI APIK telah digunakan oleh banyak UMKM. Rinandiyana et.al (2020) telah menggunakan aplikasi ini untuk melakukan pelatihan dan pendampingan UMKM di Kelurahan Cibeuti, Kota Tasikmalaya. Kemudian, Agustina, Ningsih, \& Mulyati (2021) juga melakukan pelatihan menggunakan Si APIK kepada beberapa pihak seperti PINBAS MUI, HIPMIKIMDO, LPP HIPMIKIMDO, SME Community, dan Batik Sakera yang hasil penelitiannya menunjukkan bahwa setelah diberikan pelatihan menggunakan Aplikasi Si APIK, peserta lebih paham dalam menyusun laporan keuangan.

UMKM XYZ merupakan UMKM yang berada di Jawa Tengah dengan kegiatan usahanya adalah di bidang kuliner. Berdasarkan observasi yang telah dilakukan melalui wawancara, UMKM tersebut belum melakukan pencatatan akuntansi dan pembuatan laporan keuangan berdasarkan Standar Akuntansi EMKM.

Atas permasalahan tersebut, Penulis dibantu tim mahasiswa melakuakn kegiatan edukasi dan pendampingan penyusunan laporan keuangan. Edukasi dilakukan melalui pembuatan video tutorial membuat laporan keuangan menggunakan aplikasi si APIK. Pendampingan dilakukan dengan mendampingi UMKN untuk menyusun laporan keuangan menggunakan aplikasi si APIK.

\section{METODE PELAKSANAAN}

Dalam melakukan kegiatan pengabdian masyarakat, penulis dan tim melakukan berbagai kegiatan dengan tujuan UMKM XYZ paham akan pentingnya laporan keuangan dan mampu membuat laporan keuangan menggunakan aplikasi Si APIK. Setelah melakukan observasi dengan wawancara, tim melakukan diskusi, pengambilan data, pendampingan dalam menyusun laporan keuangan. Secara umum ada dua hal utama dalam kegiatan pengabdian masyarakat tersebut, yaitu:

\section{Ide Pemecahan Masalah}

Melihat permasalahan yang sudah dibahas di atas, kegiatan pengabdian masyarakat ini bertujuan untuk melakukan edukasi dan pendampingan penyusunan laporan keuangan UMKM sesuai standar akuntansi keuangan EMKM menggunakan aplikasi Si APIK. Untuk melakukan pendampingan, perlu dilakukan observasi menyeluruh mengenai kondisi UMKM. 
Pengetahuan mengenai transksi bisnis entitas, standard operasi yang digunakan, sumber daya manusia yang ada, sampai dengan data aset dan keuangan lainnya harus tersedia. Kerjasama dengan pihak UMKM menjadi kunci keberhasilan dari kegiatan ini.

\section{Pelaksanaan Kegiatan}

Terdapat empat kegiatan utama yang dilakukan dalam program pengabdian masyarakat kali ini. Kegiatan pertama adalah perencanaan dan observasi yang dilakukan melalui wawancara dan pengumpulan data yang dibutuhkan. Tahap kedua adalah kegiatan pendampingan penyusunan laporan keuangan menggunakan aplikasi Si APIK. Tahap ketiga penyusunan laporan keuangan sampai dengan bulan Agustus 2021, dan tahap terakhir adalah pembuatan video tutorial penggunaan aplikasi SI APIK untuk menyusun laporan keuangan serta pembuatan poster mengenai penyusunan laporan keuangan.

\section{HASIL DAN PEMBAHASAN \\ Tahap Pertama}

Perencaan dilakukan melalui zoom mengingat kondisi pandemi covid-19. Perencanaan dilakukan pada 3 September 2021. Berdasarkan hasil perencanaan, maka tahap berikutnya adalah pelaksanaa observasi yang dilakukan dengan melakukan wawancara dengan pemilik UMKM terkait dengan laporan keuangan yang disusun oleh UMKM. Berdasarkan hasil wawancara tersebut dapat diidentifikasi hal-hal seperti pada tabel 1.

Tabel 1 Permasalahan

\begin{tabular}{|c|l|l|}
\hline No & \multicolumn{1}{|c|}{ Permasalahan } & \multicolumn{1}{|c|}{ Indikator } \\
\hline 1. & $\begin{array}{l}\text { UMKM XYZ belum menyusun } \\
\text { laporan keuangan secara rinci } \\
\text { dan detail. }\end{array}$ & $\begin{array}{l}\text { Objek belum merasa perlu untuk membuat } \\
\text { laporan keuangan yang rinci dan detail, dan } \\
\text { merasa bahwa pembuatan laporan keuangan } \\
\text { adalah hal yang rumit. }\end{array}$ \\
\hline 2. & $\begin{array}{l}\text { Pencatatan keuangan yang } \\
\text { masih sangat sederhana, hanya } \\
\text { mencatat uang masuk saja. }\end{array}$ & $\begin{array}{l}\text { Kurangnya pemahaman tentang manfaat } \\
\text { penyusunan dan pelaporan keuangan secara } \\
\text { lengkap. }\end{array}$ \\
\hline 3. & $\begin{array}{l}\text { Data hisoris keuangan tidak } \\
\text { ditemukan }\end{array}$ & $\begin{array}{l}\text { Belum lengkapnya pencatatan, maka banyak data } \\
\text { dan informasi yang tidak diketahui secara rinci. }\end{array}$ \\
\hline
\end{tabular}

Sumber: Hasil wawancara (2021)

Setelah melihat kondisi yang ada, memang untuk membuat laporan keuangan yang lengkap sesuai standar akuntansi keuangan sedikit kesulitan dengan tidak adanya pegawai khusus di bidang akuntansi dan data akuntansi yang lengkap. Oleh karena itu, berdasarkan permasalahan yang ada, tim memberikan beberapa solusi seperti pada tabel 2 .

Tabel 2 Solusi

\begin{tabular}{|c|c|c|c|}
\hline No & Permasalahan & $\begin{array}{c}\text { Solusi yang } \\
\text { Direkomendasikan }\end{array}$ & Alasan \\
\hline 1. & $\begin{array}{l}\text { UMKM XYZ belum } \\
\text { menyusun laporan } \\
\text { keuangan secara rinci } \\
\text { dan detail. }\end{array}$ & $\begin{array}{l}\text { Dengan memberikan } \\
\text { edukasi berupa poster } \\
\text { dan video tutorial } \\
\text { penggunaan aplikasi SI } \\
\text { APIK dan melakukan } \\
\text { pendampingan dalam } \\
\text { melakukan pencatatan } \\
\text { sampai dengan } \\
\text { menghasilkan laporan } \\
\text { keuangan. }\end{array}$ & $\begin{array}{l}\text { Dengan menggunakan aplikasi SI } \\
\text { APIK, maka dirasa akan lebih } \\
\text { mepermudah UMKM dalam } \\
\text { melakukan pencatatan dan } \\
\text { pelaporan akuntansi. }\end{array}$ \\
\hline 2. & Pencatatan keuangan & Dengan memberikan & Dengan adanya transaksi dan \\
\hline
\end{tabular}




\begin{tabular}{|l|lr|l|l|}
\hline & $\begin{array}{l}\text { yang masih sangat } \\
\text { sederhana, hanya } \\
\text { mencatat uang masuk } \\
\text { saja. }\end{array}$ & $\begin{array}{l}\text { edukasi berupa video dan } \\
\text { poster, yang menjelaskan } \\
\text { transaksi apa saja yang } \\
\text { harus dicatat dan laporan } \\
\text { apa saja yang dihasilkan } \\
\text { sesuai kebutuhan } \\
\text { UMKM. }\end{array}$ & $\begin{array}{l}\text { laporan keuangan yang lengkap, } \\
\text { dapat membuat UMKM lebih } \\
\text { mengerti secara detail mengenai } \\
\text { kondisi keuangannya. }\end{array}$ \\
\hline 3. & $\begin{array}{l}\text { kata } \\
\text { keuangan } \\
\text { ditemukan }\end{array}$ & $\begin{array}{r}\text { hisoris } \\
\text { tidak }\end{array}$ & $\begin{array}{l}\text { Dengan membuat data } \\
\text { estimasi atau perkiraan, } \\
\text { karena tidak diketahui } \\
\text { data real nya. }\end{array}$ & $\begin{array}{l}\text { Dengan menggunakan data } \\
\text { perkiraan akan dapat melengkapi } \\
\text { kebutuhan informasi, sehingga } \\
\text { edukasi kami akan lebih mudah } \\
\text { diterima oleh UMKM sebagai } \\
\text { penerima manfaat. }\end{array}$ \\
\hline
\end{tabular}

Sumber : data diolah

Dari tabel 2 di atas, maka kegiatan yang akan dilakukan oleh tim terdiri dari edukasi baik langsung maupun melalui pembuatan video dan poster, serta pendampingan penyusunan laporan keuangan.

\section{Tahap Kedua}

Tahap kedua dilakukan pendampingan penyusunan laporan keuangan. Dari hasil wawancara dan observasi yang dilakukan pada tahap pertama, langkah selanjutnya adalah melaksanakan edukasi laporan keuangan dan pendampingan penyusunan laporan keuangan. Edukasi dan pendampingan dilakukan secara online dan offline. Online dilakukan melalui aplikasi google meet dan offline dilakukan secara langsung dengan perwakilan tim melakukan diksusi langsung dengan pemilik usaha.

Edukasi dan pendampingan secara online dilakukan dengan menjelaskan pentingnya laporan keuangan, kegunaan laporan keuangan, jenis laporan keuangan dan bagaimana menyusuna laporan keuangan menggunakan aplikasi Si APIK. Sedangkan edukasi dan pendampingan secara offline dilakukan untuk menggali permasalahan yag dihadapi terkait dengan penyusunan laporan keuangan. Dari informasi yang diperoleh, kemudian dilakukan penjelasan dan pendampingan sehingga pemilik usaha paham dan mampu menyusun laporan keuangan secara mandiri.

\section{Tahap Ketiga}

Setelah melakukan dua tahap sebelumnya, untuk dapat menyusun laporan keuangan yang lengkap dan sesuai standar, maka perlu dilakukan analisis kesiapan dan kecukupan data transaksi keuangan. Berdasarkan informasi yang diperoleh, pemilik hanya melakukan pencatatan kas yang diterima dari pelanggan dan belum melakukan pencatatan atas kas yang dikeluarkan termasuk untuk membeli bahan baku. Selain itu, pemilik usaha juga tidak mencatat atas aset tetap dan aset lainnya yang terkait dengan kegiatan usaha tersebut.

Atas permasalahan pencatatan transaksi penerimaan dan pengeluaran kas, tim meminta data perkiraan yang dimiliki oleh pemilik usaha. Kemudian untuk aset tetap digunakan metode perkiraan perolehan termasuk perkiraan masa manfaatnya. UMKM tidak memiliki utang, sehingga aset yang ada, nilainya akan sama dengan nilai ekuitas atau modal. Untuk nilai penjualan juga menggunakan data perkiraan yang terjadi di bulan Agustus 2021. Kemudian untuk jenis beban dan nilanya, tim meminta penjelasan terkait dengan jumlah belanja bahan baku, pembayaran sewa tempat, pembayaran listrik, pembayaran gaji, dan beban-beban lain yang dikelurkan berdasar perkiraan pemilik usaha.

Pendampingan ini dilakukan untuk dapat menghasilkan laporan keuangan. Laporan keuangan yang dibuat dalam kegiatan pengabdian masyarakat ini adalah laporan posisi keuangan per 31 Agustus 2021, laporan laba rugi dan laporan arus kas untuk periode yang 


\section{PENGMASKU}

Volume 1 No. 1, Juni 2021

berakhir pada 31 Agustus 2021. Laporan posisi keuangan per 31 Agustus 2021 menunjukkan total aset sebesar Rp39.193.249,99 dengan asumsi nilai yang dapat diverifikasi per 31 Agustus 2021.

Kemudian nilai liabilitasnya adalah nol karena perusahaan melakukan kegiatan pembelian dan pembayaran beban secara kas. Atas nilai liabilitas nol rupiah, maka nilai ekuitas akan sama dengan nilai total aset sebesar Rp39.193.249,99 yang terdiri dari modal awal sebesar Rp25,232,000 dan laba ditahan sebesar Rp13.961.249,99.

Selanjutnya, laporan laba rugi mencatatkan penjualan bulan Agustus sebesar Rp32.508.000. Jumlah beban usaha yang terjadi sebesar Rp18.546.750,01. Sehingga total laba bersih yang diterima adalah Rp13.961.249,99. Untuk laporan arus kas, kas yang diterima periode Agustus 2021 adalah sebesar Rp32.508.000 dan kas yang dikeluarkan periode Agustus 2021 adalah sebesar Rp23.739.000, sehingga perubahan kas bersihnya sebesar Rp8.769.000. Saldo kas akhir Agustus 2021 adalah sebesar Rp14.001.000 karena saldo awal kas pada Agustus 2021 adalah Rp5.232.000.

\section{Tahap Keempat}

Tahap keempat adalah penyusunan video tutorial penyusunan laporan keuangan UMKM XYZ dan poster mengenai pentingnya menyusun laporan keuangan. Video tersebut dibuat untuk dijadikan pedoman pagi perusahaan dalam menggunakan SI APIK untuk menyusun laporan keuangannya. Poster disusun untuk memberikan pemahaman pentingnya menyusun laporan keuangan. Di dalam poster dijelaskan mengenai pengertian laporan keuangan, manfaat, tujuan, dan cara menyusunnya menggunakan aplikasi Si APIK.

\section{PENUTUP}

\section{Simpulan}

Kegiatan pengabdian masyarakat dalam bentuk edukasi dan pendampingan penyusunan laporan keuangan pada UMKM XYZ bertujuan untuk memberikan pengetahuan mengenai pentingnya laporan keuangan dan bagaimana menyusun laporan keuangan, serta mendampingi mitra untuk menyusun laporan keuangan menggunakan aplikasi SI APIK.

Kegiatan pengabdian masyarakat ini dilakukan secara offline dan online. Kegiatan secara offline dilakukan pada saat pencarian mitra, diskusi dan pengambilan data, serta pada saat penyerahan output. Kegiatan online dilakukan melalui zoom dan google meet.

Hasil yang diharapkan dari kegiatan ini adalah mitra paham dan mampu dalam menyusun laporan keuangan sendiri melalui aplikasi akuntansi SI APIK. Untuk memudahkan mitra mengingat proses penyusunan laporan keuangan, tim telah membuat dan menyerahkan video dan poster panduan penyusunan laporan keuangan UMKM. Selain itu, dari kegiatan ini, juga telah dihasilkan laporan keuangan periode Agustus 2021 yang dihasilkan dari proses pendampingan penyusunan laporan keuangan.

\section{Saran}

Atas penjelasan di atas, penulis memberikan saran agar pemilik usaha dapat menunjuk satu orang yang bertugas melakukan pencatatan. Hal ini agar pencatatan menjadi andal dan dapat menunjukkan dengan tepat mengenai pendapatan, beban, aset, laba dan kekayaan perusahaan.

\section{DAFTAR PUSTAKA}

Agustina, Y., Ningsih, S. S., \& Mulyati, H. (2021). No Title. Intervensi Komunitas, 2(2), 134145. Retrieved from http://ojs.itb-ad.ac.id/index.php/IK/article/view/871/271

Fadila, R. U. (2020, May 9). 1.785 Koperasi dan 163.713 UMKM Terdampak Pandemi Covid19. Www.Pikiran-Rakyat.Com. Retrieved from https://www.pikiranrakyat.com/ekonomi/pr-01379615/1785-koperasi-dan-163713-umkm-terdampak- 


\section{PENGMASKU}

Volume 1 No. 1, Juni 2021

pandemi-covid-19

Haryanti, D. M., \& Hidayah, I. (2019, July 29). Potret UMKM Indonesia: Si Kecil yang Berperan Besar. Ukmindonesia.Id. Retrieved from https://www.ukmindonesia.id/bacaartikel/62

Kementerian Keuangan. (2021, September 27). Pemerintah Terus Perkuat UMKM Melalui Berbagai Bentuk Bantuan. Retrieved December 4, 2021, from https://www.kemenkeu.go.id/publikasi/berita/pemerintah-terus-perkuat-umkm-melaluiberbagai-bentuk-bantuan/

Rasti, R. (2021, January 5). Ekspor UMKM Ditargetkan Meningkat Jadi 15,12 Persen di 2021. Retrieved December 3, 2021, from https://mnews.co.id/read/fokus/ekspor-umkmditargetkan-meningkat-naik-jadi-1512-persen-di-2021/

Rinandiyana, L. R., \& Kusnandar, D. L., \& Rosyadi, A. (2020). PEMANFAATAN APLIKASI AKUNTANSI BERBASIS ANDROID (SIAPIK) UNTUK MENINGKATKAN ADMINISTRASI KEUANGAN UMKM. Qardhul Hasan: Media Pengabdian Kepada Masyarakat, 6(1), 73-78. https://doi.org/https://doi.org/10.30997/qh.v6i1.2042

Santia, T. (2021, January 5). Ekspor UMKM Ditargetkan Meningkat Jadi 15,12 Persen di 2021. Retrieved 2021,

from https://www.liputan6.com/bisnis/read/4449216/ekspor-umkm-ditargetkan-meningkatjadi-1512-persen-di-2021 